\title{
A Corpus-Based Study on English Prepositions of Place, in and on
}

\author{
Asmeza Arjan $^{1,2}$, Noor Hayati Abdullah ${ }^{1,2} \&$ Norwati Roslim ${ }^{3}$ \\ ${ }^{1}$ Faculty of Educational Studies, Universiti Putra Malaysia, Serdang, Selangor, Malaysia \\ ${ }^{2}$ English Language Department, Centre of Language and Pre-University Academic Development Centre for \\ Foundation Studies, International Islamic University Malaysia, Petaling Jaya, Selangor, Malaysia \\ ${ }^{3}$ English Language Department, Academy of Language Studies, Universiti Teknologi MARA, Negeri Sembilan, \\ Kampus Kuala Pilah, Beting, Kuala Pilah, Negeri Sembilan, Malaysia \\ Corespondence: Asmeza Arjan, English Language Department, Centre of Language \& Pre-University Academic \\ Development Centre for Foundation Studies, International Islamic University Malaysia, Petaling Jaya, 46350 \\ Selangor, Malaysia. Tel: 60-6-7946-3001. E-mail: asmeza@iium.edu.my
}

\author{
Received: May 22, 2013 Accepted: October 9, 2013 Online Published: November 5, 2013 \\ doi:10.5539/elt.v6n12p167 URL: http://dx.doi.org/10.5539/elt.v6n12p167
}

\begin{abstract}
This corpus-based study examined the usage, mastery and developmental pattern (Norwati, 2004) of English prepositions of place, in and on across three different academic levels namely Form 4, Form 5 and College students. The Malaysian Corpus of Students Argumentative Writing (MCSAW) was used as the source of data in analyzing the use of prepositions of place, in and on in the students' argumentative essays. In achieving this, the concordance output was utilized to determine the frequency and types of errors made by students. This paper also presents other common errors in relation to the usage of these two prepositions. The findings showed that in terms of mastery levels and developmental pattern, there was no steady progress from Form 4 to Form 5. Yet, the College students managed to show a positive development in the use of prepositions of place, in and on. The findings also revealed that students are confused between in and on as well as using them with or without articles correctly. The findings of this study can benefit English teachers in teaching prepositions of place and the use of MCSAW can be fully utilized by teachers for further future researches.
\end{abstract}

Keywords: prepositions of place in and on, corpus-based study, argumentative

\section{Introduction}

Grammar has always been considered as an essential substance in teaching English especially in English as a second language environment such as in Malaysia (Mukundan \& Norwati, 2009). Prepositions can be perceived as one of the difficult topics to be mastered by the second language learners. However, they still need to be taught because of the high level of importance in the grammatical system and eventually in the learning of the language. According to Morenberg (1997), prepositions are always considered as the most crucial elements in teaching English particularly in the teaching of speaking and writing skills (as cited in Mukundan \& Norwati, 2009).

As mentioned by Tetreault and Chodorow (2008), the errors which deal with prepositions are the most common mistakes done by the non-native speakers especially in their writing. This could be due to a wide range of linguistic functions that prepositions serve, hence ESL learners may feel discouraged to learn and master this grammar topic. For example, in choosing the appropriate preposition, one has to know and understand the context as well as "the intended meaning" (Tetreault \& Chodorow, 2008) of what to be conveyed. This can be seen in these examples, "we sat at the beach", "on the beach", "near the beach", "by the beach" (Tetreault \& Chodorow, 2008). In relation to this, the researchers are called to choose the prepositions of place as the main subject matters as these are among one of the main problems faced by Malaysian students regardless of their age groups.

\subsection{Objectives of the Study}

The objectives of this study are to identify the errors in the use of prepositions of place, in and on among Form 4, Form 5 and College students in their argumentative essays and to determine the frequency of these errors occur in their argumentative essays. 


\subsection{Research Questions}

Pertaining to the objectives above, this study attempts to answer these two research questions:

1) What are the distribution patterns of prepositions of place, in and on?

2) What are the common errors in the use of prepositions of place in and on?

\section{Literature Review}

\subsection{Prepositions in English}

Musliyanti defines preposition as, “... a word that shows the relationship between two words in a sentence. Prepositions are always followed by nouns (or pronouns). They are connective words that show the relationship between the nouns following them and one of the basic sentences elements: subject, verb, object, or complement. They usually indicate relationship, such as position, place, direction, time, manner, agent, possession, and condition, between their objects and other parts of the sentence" (2012, p. 2).

Even though prepositions may seem insignificant, they in actual fact have a very important role to play in the teaching and learning of English. However, having a wide range of "linguistic functions" (Tetreault \& Chodorow, 2008), this has somehow led to a certain level of difficulty particularly confusion among the second language learners. The confusion normally happens when the learners are uncertain about which prepositions to be used in almost similar contexts. This has been proved in many extensive studies and work done by renowned linguists from the past to present. As stated by Swan (1998).

"It is difficult to learn to use prepositions correctly in a foreign language. Most English prepositions have several different functions (for instance, one well- known dictionary lists eighteen main uses of at), and these may correspond to several different preposition in another language. At the same time, different preposition can have very similiar uses (in the morning, on Monday morning, at night) ......" (As cited in Musliyanti, 2012, p. 3).

What Swan has mentioned above more than a decade ago is still haunting the learners as well as the teachers of English as a Second Language (ESL). The study done by Mukundan and Norwati (2009) had revealed that all the difficulties in relation to prepositions for teachers and learners are caused by "the nature and complexity of prepositions" itself. Apart from that, the findings from Saadiyah and Subramaniam's study (2009) also showed that out of 15 types of errors made by the students, preposition has been ranked in the fourth place as the most frequent errors done by the students. All of these findings do support the idea that preposition is very important to be taught and to be learned regardless of the accompanying difficulties and challenges.

With all the justifications for prepositions above, it leads the writers to find out the students' ability in using English prepositions of place, in and on, the frequency occurrence of the errors and in which parameters do these errors violate.

\subsection{Prepositions of Place in and on}

There was some confusion among students as to whether they need to use in or on, in their writing. This confusion could be related to some characteristics which have been listed by Carillo in his online forum. Some of the characteristics of prepositions mentioned by him are: it is mainly conventional, it sometimes carries elements of oddity, and most of the preposition choices in actual fact do not have "inherent or discernible logic of their own" (2009). He also stated that, it is difficult to plausibly comprehend and differentiate the difference between in and on when they are used "as prepositions of place and location" (2009). Eventually, this confusion leads to the misuse of prepositions of place, in and on, and this is one of the major reasons of why most of the ESL learners have difficulty in mastering this particular grammar topic and they require longer time in order to be able to proficiently apply the knowledge in their writing and speaking skills.

In a study conducted by Eissa Al-Khotoba (2013), her findings showed that the Arabs ESL speakers did commit significant errors when using prepositions of place in and on. Zohre and Goodarz (2012) also signified that 53\% of their samples had problems with the correct usage of prepositions. Out of this percentage, $64 \%$ of them had problems in using prepositions of place. This strongly shows how pertinent it is for this issue to be addressed.

There is also another factor that contributes to this situation, the comparison between the first language (L1) and the second language (L2). Some ESL learners have problems to use them correctly as they are being influenced by their L1. To illustrate further, Nipissing University revealed that a number of Spanish students found it difficult to use prepositions of place, in and on. This problem heightens since Spanish uses only a single preposition, en, for in and on. Unlike Spanish, English has two different prepositions which function differently, in and on (2013). That is why these students could not differentiate the usage of in and on in L2, due to the interference of the learners' L1 schemata. 
In another similar study done by Tutin Apriyani (2012), she found out that her samples, Indonesian employees, had problems in using in, on as well as at correctly. Likewise, Nor Hashimah, Norsimah and Kesumawati also discovered that one of the problems of using prepositions is when the students "...literally translates the options into Malay" (2008) which is the learners' L1.

In brief, in order to be able to use prepositions of place in the right context, it requires the ESL learners to have a significant amount of knowledge and mastery level which will help the learners to employ what they have comprehended in reading, listening, writing and speaking skills. Unfortunately, most students have not achieved this, thus, leading to their inability to use the prepositions of place in and on effectively.

\section{Methodology}

\subsection{Corpus-Based Analysis}

This corpus-based study looks at Malaysian Corpus of Students Argumentative Writing (MCSAW) developed by Mukundan and Rezvani Kalajahi (2013), a corpus of argumentative essay from three different categories of students: Form 4, Form 5 and College students. It utilizes a computer software WordSmith Tools version 4.0.

\subsection{Word Smith Tools}

This study uses Wordsmith Tools 4.0 which has three analysis tools namely WordList, Concord and KeyWords. This study utilizes only one analysis tool, Concord, that analyses in detail on concordance entries for each preposition. Concord has helped in listing the specific prepositions to be studied and providing the total of running words for the relevant prepositions.

\subsection{The Subjects}

The 1010 subjects of this study were Form 4, Form 5 and College students from a few schools and institutions in Selangor and Negeri Sembilan, Malaysia. The average age range is 18 . These students have been exposed to learning English for at least ten to twelve years.

Tables 1 and 2 illustrate the frequency and percentage of the subjects according to gender and ethnicity respectively.

Table 1. Frequency and percentage of respondents according to gender

\begin{tabular}{lll}
\hline Frequency Percent & & \\
& Frequency & Percentage \\
\hline Male & 414 & 41.0 \\
Female & 596 & 59.0 \\
Total & 1010 & 100.0 \\
\hline
\end{tabular}

Table 2. Frequency and percentage of respondents according to ethnicity

\begin{tabular}{lll}
\hline Frequency Percent & & \\
& Frequency & Percentage \\
\hline Malay & 676 & 66.9 \\
Chinese & 254 & 25.1 \\
Indian & 80 & 7.9 \\
Total & 1010 & 100.0 \\
\hline
\end{tabular}

\subsection{Data Collection Procedures}

Only written data in the form of an essay were collected from the students. The essay was an argumentative essay entitled "Do you think Facebook has more advantages than disadvantages? Discuss your reasons." The MA candidates instructed their students to write a 250 words essay. This type of essay was chosen based on the primary criteria of being able to generate extensive language and vocabulary use, sense of familiarity to the students, as well as control of language support.

Printouts on concordances of the English prepositions of place, in and on, in the essays were extracted and used as analysis sheets. The concordance output was then edited by removing all the prepositions which were not relevant to the use of prepositions of place, in and on. The frequency in the use of $i n$ as a preposition of place by 
Form 4 was 328, Form 5 was 356 and College was 635 . Thus, the total of frequency was 1319 . Whereas, for the frequency of on as a preposition of place by Form 4 was 424, Form 5 was 348 and College was 342. This gives a total of 1114 .

\subsection{Data Analysis Procedures}

The descriptions of data analysis will be presented in terms of mastery level, developmental pattern and categories of errors.

\section{Mastery Level}

The standard for mastery on the use of in and on was set at $80 \%$ correct in finding out whether or not the students have mastered the items. This standard for mastery was based on the characteristics of criterion-referenced testing which is commonly used in mastery testing (Gronlund, 1993, p.135, as cited in Norwati, 2004).

\section{Developmental Patterns}

In examining the developmental patterns, the figures in table 3 and table 4 were analysed in terms of the correct use of these prepositions and the frequency of use for these prepositions.

\section{Categorising Errors}

The students' errors were listed and were then categorised accordingly. The categorisation of errors was based on the violation of the set parameters. There are two sets of parameters used in analyzing and categorizing the errors. Each set has six parameters as guidelines for analysis in order to determine the correct use of the prepositions of place, in and on. For each parameter, the errors were counted in determining the raw frequency of occurrences and the figures were then converted into percentage. Table 3 further illustrate the parameters of the correct use of the preposition in and Table 4 presents the parameters of the correct use of the preposition on in detail.

Table 3. Parameters of the correct use of the preposition in as a preposition of place

\begin{tabular}{l}
\hline Parameter \begin{tabular}{l} 
Description \\
\hline 1 \\
In is used to show a three-dimensional object which in reality it is \\
(when something is surrounded on all sides). \\
Example: (a) There are only two beds in the cottage. \\
Other examples: (a) in a box \\
(b) in the bathroom \\
(c) in the cathedral
\end{tabular} \\
In is used to show a two-dimensional object which in reality it is \\
(when something is in an enclosed area). \\
Example: (a) The cows are in the field. \\
Other examples: (a) in the world \\
$\quad$ (b) in the village \\
(c) in a park \\
In is used with an article, a, an or the, and a noun to show place: (in + a/an/the + a noun). \\
Examples: (a) The mysterious gift is in a box. \\
(b) She sits comfortably in an armchair. \\
(c) There is no one in the room.
\end{tabular}


The first two parameters (1 and 2) were taken from Quirk, Greenbaum, Leech \& Svartvik (1985, p. 674-677). Whereas, for parameters 3-6, they were cited from Norwati $(2004$, p. 133) which were taken from Murphy (1986, p. 234-235) for parameters 3 and 5, Tan (1994, p. 82) for parameter 4 and Hughes (1992, p. 91-92) for parameter 6.

Table 4. Parameters of the correct use of the preposition on as a preposition of place

\begin{tabular}{|c|c|}
\hline Parameter & Description \\
\hline \multirow[t]{6}{*}{1} & $\begin{array}{l}\text { On is used to show one-dimensional/ two-dimensional areas (when something is viewed as a } \\
\text { line / a surface). }\end{array}$ \\
\hline & Examples: (a) Our cottage is on that road. \\
\hline & (b) The city is situated on the River Thames / on the boundary / on the coast. \\
\hline & Examples: (a) There is some ice on that road. \\
\hline & (b) There is a new roof on the cottage. \\
\hline & (c) A notice was pasted on the wall / on the ceiling / on my back. \\
\hline \multirow[t]{4}{*}{2} & On is used with an article, $\mathrm{a}$, an or the, and a noun to show place: $($ on + a/an/the + a noun $)$. \\
\hline & Examples: (a) She stands on a stool. \\
\hline & (b) I've got a cottage on an island. \\
\hline & (c) They put the vases on the floor. \\
\hline \multirow[t]{2}{*}{3} & $\begin{array}{l}\text { On is used with a noun without an article, a, an or the, to show place in some fixed expressions: } \\
(\text { on }+ \text { a noun }) \text {. }\end{array}$ \\
\hline & Example: (a) You'll find the poem on page 32. \\
\hline \multirow[t]{2}{*}{4} & $\begin{array}{l}\text { On is used with an article, a, an or the, followed by an adjective/adjectives before the noun to } \\
\text { describe the place: (on }+ \text { a/an/the }+ \text { adjective/s }+ \text { a noun). }\end{array}$ \\
\hline & Example: (a) He stands on a wooden chair. \\
\hline \multirow[t]{2}{*}{5} & $O n$ is used with possessive adjective: (on + possessive adjective). \\
\hline & Example: (a) She carried her baby on her back. \\
\hline \multirow[t]{2}{*}{6} & On is used with the of structure: (on + the of structure). \\
\hline & Example: (a) Write your name on the back of this piece of paper. \\
\hline
\end{tabular}

Parameter 1 were taken from Quirk et al. (1985, p. 674-677). Whereas, for parameters 2-6, they were cited from Norwati (2004, p. 133) which were taken from, Murphy (1986, p. 234-235) for parameters 2 and 4, Tan (1994, p. 82) for parameter 3, Hughes (1992, p.91) for parameter 5 and Swan $(1988$, p.88) for parameter 6.

\section{Results and Discussion}

This section presents the results of the analysis and the discussion on the mastery level, developmental patterns and the categories of errors. The following tables display the frequency and the percentage of the correct use of in and on as the prepositions of place in the argumentative essay for Form 4, 5 and College students.

Table 5. Frequency and percentage of the correct use of in as a preposition of place

\begin{tabular}{|c|c|c|c|c|c|c|c|c|}
\hline & & $\mathrm{P} 1$ & $\mathrm{P} 2$ & P3 & P4 & P5 & P6 & Total \\
\hline \multirow[t]{2}{*}{ Form 4} & $f$ & $15 / 15$ & $182 / 183$ & $10 / 10$ & $39 / 42$ & $57 / 60$ & $18 / 18$ & $321 / 328$ \\
\hline & $\%$ & 100 & 99.45 & 100 & 92.86 & 95 & 100 & 97.87 \\
\hline \multirow[t]{2}{*}{ Form 5} & $f$ & $35 / 36$ & $163 / 164$ & $27 / 27$ & $33 / 36$ & $66 / 73$ & $20 / 20$ & $344 / 356$ \\
\hline & $\%$ & 97.23 & 99.39 & 100 & 91.67 & 90.41 & 100 & 96.63 \\
\hline \multirow[t]{2}{*}{ College } & $f$ & $95 / 95$ & $278 / 278$ & $95 / 95$ & $64 / 64$ & $63 / 70$ & $30 / 33$ & $625 / 635$ \\
\hline & $\%$ & 100 & 100 & 100 & 100 & 90 & 90.91 & 98.43 \\
\hline
\end{tabular}

Based on Table 5, the Form 4 students were able to correctly use the preposition in with $97.87 \%$ or 321 out of 328 occurrences were correct. The Form 5 students obtained $96.63 \%$ or 344 out of 356 occurrences were correct. Finally, the College students produced $98.43 \%$ or 625 out of 635 correct occurrences. 
Concerning the students' mastery levels of using the prepositions of place, in, the findings show quite a surprising outcome as the Form Five students achieved slightly lower than the Form 4 students by $1.24 \%$ of difference. However, as expected, the College students showed a very encouraging performance at $98.43 \%$.

As for the developmental pattern, there was no steady progress from Form 4 to Form 5. Yet, the College students managed to show a positive development in the use of preposition of place, in.

Table 6. Frequency and percentage of the correct use of on as a preposition of place

\begin{tabular}{|c|c|c|c|c|c|c|c|c|}
\hline & & P1 & P2 & P3 & $\mathrm{P} 4$ & P5 & P6 & Total \\
\hline \multirow[t]{2}{*}{ Form 4} & $f$ & $9 / 11$ & $60 / 73$ & $288 / 294$ & $12 / 12$ & $19 / 22$ & $2 / 4$ & $390 / 416$ \\
\hline & $\%$ & 81.82 & 82.2 & 97.96 & 100 & 86.36 & 50 & 93.75 \\
\hline \multirow[t]{2}{*}{ Form 5} & $f$ & $2 / 5$ & $52 / 71$ & $218 / 228$ & $11 / 11$ & $30 / 30$ & - & $313 / 345$ \\
\hline & $\%$ & 40 & 73.24 & 95.61 & 100 & 100 & - & 90.73 \\
\hline \multirow[t]{2}{*}{ College } & $f$ & $4 / 4$ & $70 / 74$ & $192 / 204$ & $21 / 21$ & $37 / 37$ & $2 / 2$ & $326 / 342$ \\
\hline & $\%$ & 100 & 94.60 & 94.12 & 100 & 100 & 100 & 95.32 \\
\hline
\end{tabular}

Based on Table 6, the Form 4 students were able to correctly use the preposition on with $93.75 \%$ or 390 out of 416 occurrences were correct. However, the Form 5 students only obtained $90.73 \%$ or 313 out of 345 occurrences were correct. Lastly, the College students produced $95.32 \%$ or 326 out of 342 correct occurrences.

The findings in the students' mastery levels of using the prepositions of place, on, reveal a relatively an unexpected outcome as the Form Five students achieved much lower than the Form 4 students by $3.02 \%$ of difference. Conversely, the College students showed a better performance at $95.32 \%$.

In terms of the developmental pattern, it can be said that there was no steady improvement from Form 4 to Form 5. Yet, the College students managed to show a progressive development in the use of preposition of place, on.

\subsection{Categories of Errors}

The categorisation of errors was based on the violations of the set parameters. These errors were identified as common errors when the two or three groups violated the same categories. Tables 7 and 8 show the categories of common errors for prepositions in and on respectively.

Table 7. The categories of common errors in the use of preposition of place, in

\begin{tabular}{llll}
\hline \multirow{2}{*}{ Parameter } & Levels & & \\
\cline { 2 - 4 } & Form 4 & Form 5 & College \\
\hline 1 & $\sqrt{ }$ & $\sqrt{ }$ & \\
2 & & & \\
3 & $\sqrt{ }$ & $\sqrt{ }$ & $\sqrt{ }$ \\
4 & $\sqrt{ }$ & $\sqrt{ }$ & \\
5 & & & \\
6 & & & \\
\hline
\end{tabular}

Table 8. The categories of common errors in the use of preposition of place, on

\begin{tabular}{llll}
\hline \multirow{2}{*}{ Parameter } & Levels & & \\
\cline { 2 - 4 } & Form4 & Form 5 & College \\
\hline 1 & $\sqrt{ }$ & $\sqrt{ }$ & \\
2 & $\sqrt{ }$ & $\sqrt{ }$ & $\sqrt{ }$ \\
3 & $\sqrt{ }$ & $\sqrt{ }$ & \\
4 & & & \\
5 & & & \\
6 & & & \\
\hline
\end{tabular}




\subsection{Violation of Parameters for in}

\section{Parameter 2}

In the use of the preposition in, the Form 4 and Form 5 students violated parameter 2 in Table 3, in which the preposition in was replaced with on when showing a two-dimensional object which in reality it is.

Example: (a) Facebook is the most popular social network on [in] the world.

Parameter 4

In the use of the preposition in, the Form 4 and Form 5 students violated parameter 4 in Table 3, in which in is used with a noun without an article to show place.

Example: (a)....in the [-] overseas.

\section{Parameter 5}

In the use of the preposition in, all the three groups, the Form 4, Form 5 and College students violated parameter 5 in Table 3, in which in is used with an article followed by an adjectives before the noun to describe the place.

Example: (a)...in [the] same house.

(b)... in a foreign [country].

\subsection{Violation of Parameters for on}

Parameter 1

In the use of the preposition on, the Form 4 and Form 5 students violated parameter 1 in Table 4 , in which the preposition on is used to show one-dimensional/ two-dimensional areas.

Example: (a)...connected with their old friends on [in] overseas.

Parameter 2

In the use of the preposition on, all the three groups, the Form 4, Form 5 and College students violated parameter 2 in Table 4, in which on is used with an article, a, an or the, and a noun to show place.

Example: (a)...Social network that can be found on [the] Internet.

Parameter 3

In the use of the preposition on, all the three groups, the Form 4, Form 5 and College students violated parameter 3 in Table 4, on is used with a noun without an article, a, an or the, to show place.

Example: (a)...you are online on the [-] Facebook.

\section{Teaching Implication}

The findings of this corpus-based study offer some insights on the teaching of English. As teachers, this study can benefit them by showing a clear description of the exact errors committed by the students when they use the prepositions of place. Hence, this could help the teachers to come to a greater understanding of their students' problematic areas in learning prepositions. Eventually, this can assist them in planning a more creative and innovative lesson plans as well as selecting suitable materials to be used in reducing the errors.

A study done by Zohre and Goodarz (2012) particularly proved that the use of corpus-based study has a significant impact on learning prepositions by the Iranian language learners. According to them, it can decrease the number of errors produced by the students. This genre of study can also expand greater opportunities for ESL learners in mastering English grammar specifically and the language generally. In the long run, this could lead to better accuracy and fluency in learning L2, thus resulting the ESL learners to attain substantial level of proficiency in the language.

\section{Conclusion}

This corpus-based study has revealed findings on the use of prepositions of place, in and on. There were three aspects which had been discussed: the mastery levels, the developmental patterns and the common errors. The results had shown that the subjects did face some challenges in using these two prepositions of place in their argumentative essay writing.

With this in mind, teachers should be more proactive in finding solutions in terms of material selection and preparation in order to ensure the teaching and learning of English can be more effective and practical for the students to use in their daily life. 
In the aspect of professional development, there is a possibility that teachers will improve themselves tremendously not only in their career but also in becoming better persons. Apart from that, teachers can also gain a sense of satisfaction in fulfilling their roles as educators.

By using MCSAW as a source of data, it is hoped that it can contribute to a greater expansion of research for future investigations in other areas of second language teaching and learning.

\section{References}

Carillo, J. (2009). “Lesson \#8 - Specific Rules for Preposition Usage”. English Grammar, June 19, 2009, Jose Carillo's English Forum. Retrieved from http:// josecarilloforum.com/forum /index.php?topic=139.0

Eissa Al-Khotoba. (2013). Errors in the Use of Prepositions and Adverb Particles by Arabs ESL Speakers: Performance Analysis Perspective. International Journal of Linguistics, 5(1), 273-282. http://dx.doi.org/10.5296/ijl.v5i1.3310

Mukundan, J., \& Norwati Roslim. (2009). Textbook Representation of Prepositions. English Language Teaching, 2(4), 13-34. Retrieved from http://www.ccsenet.org/journal/index.php/elt/article/view/4440

Mukundan, J., \& Rezvani Kalajahi, S. A. (2013). Malaysian Corpus of Student Argumentative Writing. Australia, Australian International Academic Centre.

Musliyanti Binti Mus. (2012). Students' Ability in Using Preposition: A Case Study at Faculty of Letters of Hasanuddin University. Retrieved from http://repository.unhas.ac.id

Nipissing University, Student Development Department. (2013). Retrieved from www.nipissingu.ca/departments/student-development..../Prepositions.docx

Nor Hashimah Jalaluddin, Norsimah Mat Awal, \& Kesumawati Abu Bakar. (2008). The Mastery of English Language among Lower Secondary School Students in Malaysia: A Linguistic Analysis. European Journal of Social Sciences, 7(2), 106-199. $\quad$ Retrieved from http://www.teo-education.com/teophotos/albums/userpics/ ejss_7_2_09.pdf

Norwati Roslim. (2004). A Corpus-based Study on an English Preposition of Place, at. A paper presented at the Fifth Malaysia International Conference on English Language Teaching (MICELT) in Melaka, organized by Universiti Putra Malaysia.

Quirk, R., Greenbaum, S., Leech G., \& Svartvik, J. (1985). Comprehensive Grammar of the English Language. New York: Longman Group Ltd.

Saadiyah Darus, \& Subramaniam, K. (2009). Error Analysis of the Written English Essays of Secondary School Students in Malaysia: A Case Study. European Journal of Social Sciences, 8(3), 483-495.

Tutin Apriyani. (2012) An Analysis on Grammatical Errors made by the employee in PT, Segar Prima Jaya Batam. In Nika Purwati, et. al. (Eds.), Research in English and Applied Linguistics. Indonesia: Halaman Moeka \& LLK Publishing.

Tetreault, J. R., \& Chodorow, M. (2008). The Ups and Downs of Preposition Error Detection in ESL Writing. Retrieved from http://www.cs.rochester.edu/ tetreaul/tetreault-chodorow-coling08.pdf

Zohre Hadi, \& Goodarz Alibakhshi. (2012). On the Effectiveness of Corpus Analysis Tool in the Use of Correct Preposition in Persian into English Translation. The Iranian EFL Journal, 8, 284-294. Retrieved from http://www.iranian-efl-journal.com/October-2012-zh.php

\section{Copyrights}

Copyright for this article is retained by the author(s), with first publication rights granted to the journal.

This is an open-access article distributed under the terms and conditions of the Creative Commons Attribution license (http://creativecommons.org/licenses/by/3.0/). 